\title{
A NOVEL OSMOSIS MEMBRANE BIOREACTOR-MEMBRANE DISTILATION HYBRID SYSTEM FOR WASTEWATER TREATMENT AND REUSE
}

Nguyen Cong Nguyen ${ }^{\mathrm{a}, \mathrm{e}}$, Hau Thi Nguyen ${ }^{\mathrm{a}, \mathrm{e}}$, Shiao-Shing Chen ${ }^{\mathrm{a}^{*}}$, Huu Hao Ngo ${ }^{\mathrm{b}}$, Wenshan Guo $^{\mathrm{b}}$, Wen Hao Chan ${ }^{\mathrm{a}}$, Saikat Sinha Ray ${ }^{\mathrm{a}}$, Chi-Wang Li ${ }^{\mathrm{c}}$, Hung-Te Hsu ${ }^{\mathrm{d}}$

${ }^{a}$ Institute of Environmental Engineering and Management, National Taipei University of Technology, No.1, Sec. 3, Chung-Hsiao E. Rd, Taipei 106, Taiwan, ROC

${ }^{b}$ School of Civil and Environmental Engineering, Faculty of Engineering and InformationTechnology, University of Technology Sydney, Broadway, NSW2007, Australia ${ }^{c}$ Department of Water Resources and Environmental Engineering, TamKang University, 151 Yingzhuan Road, Tamsui District, New Taipei City 25137, Taiwan, ROC

${ }^{d}$ Department of Environmental Engineering, Chung Yuan Christian University, Chung Li 32023, Taiwan, ROC

${ }^{\mathrm{e}}$ Faculty of Environment and Natural Resources, Da Lat University, Vietnam *Corresponding authors :

E-mail address: f10919@ntut.edu.tw (Shiao-Shing Chen), Tel: +886-2-2771-2171 ext 4142, Fax:+886-2-2721-4142

\section{Abstract}

A novel approach was designed to simultaneously enhance nutrient removal and reduce membrane fouling for wastewater treatment using an attached growth biofilm (AGB) integrated with an osmosis membrane bioreactor (OsMBR) system for the first time. In this study, a highly charged organic compound $\left(\operatorname{HEDTA}^{3-}\right)$ was employed as a novel draw solution in the AGB-OsMBR system to obtain a low reverse salt flux, maintain a healthy 
environment for the microorganisms. The AGB-OsMBR system achieved a stable water flux of $3.62 \mathrm{~L} / \mathrm{m}^{2} \mathrm{~h}$, high nutrient removal of $99 \%$ and less fouling during a 60-day operation. Furthermore, the high salinity of diluted draw solution could be effectively recovered by membrane distillation (MD) process with salt rejection of $99.7 \%$. The diluted draw solution was re-concentrated to its initial status $(56.1 \mathrm{mS} / \mathrm{cm})$ at recovery of $9.8 \%$ after 6 hours. The work demonstrated that novel multi-barrier systems could produce high quality potable water from impaired streams.

Keywords: osmosis membrane bioreactor (OsMBR); attached growth biofilm (AGB); draw solution, high charge, membrane distillation (MD).

\section{Introduction}

Of all the sustainable water reuse technologies, membrane bioreactor (MBR) is the most feasible and has been employed in real applications (Guo et al., 2012; Luo et al., 2015). More attention is being placed on MBR systems because of their distinctive advantages, such as high quality of product water, low footprint, short hydraulic retention time, and reduced sludge production due to high biomass concentration in the bioreactor, and very high rejection of suspended solids (rejection $>99 \%$ ) and particles (turbidity rejection $>98 \%$ ) (Kraume and Drews, 2010; Wang et al., 2016). However, the widespread application of MBRs is challenged by the high operational costs associated with membrane fouling (Kraume and Drews, 2010; Qiu and Ting, 2013). Membrane fouling lowers productivity, increases energy requirements, and increases frequency of membrane cleaning and replacement, and may result in deterioration of treated water quality (Le-Clech et al., 2006). Hence, various technologies are currently being developed to overcome these limitations of conventional MBRs. In recent years, an innovative MBR process using a forward osmosis (FO) membrane instead of a microporous membrane (conventional MBR) has been developed: the osmosis membrane bioreactor (OsMBR) (Achilli et al., 2009; Cornelissen et al., 2008) to reduce fouling and 
enhance rejection of dissolved species and small particles. FO membrane has a few advantages, these being: (i) low energy consumption because of the use of osmotic pressure instead of hydraulic pressure as the driving force; (ii) high rejection of various contaminants, thus increasing the quality of the product water; and (iii) low fouling propensities resulting from the dense and tight surface structure of the FO membrane (Nguyen et al., 2015; Nguyen et al., 2016; Wang et al., 2016; Yin Tang and Ng, 2014). Therefore, OsMBR is considered as a multiple-barrier technology, well suited for indirect and direct potable water reuse applications (Achilli et al., 2009; Alturki et al., 2012).

Nevertheless, a major technical challenge to OsMBR application was the lack of appropriate draw solutions that could reduce salt accumulation and membrane fouling during long-term operation (Ge et al., 2012; Holloway et al., 2015a; Wang et al., 2016). Yap et al. (2012) demonstrated that the reverse salt flux from the draw solution into the bioreactor and the high salt rejection by the FO membrane caused the build-up of salinity in the in OsMBR systems. Increased bioreactor salinity can severely impact on microbial viability and membrane performance because some functional bacteria are more sensitive to high salinity conditions (Osaka et al., 2008). Kinetics studies have suggested that nitrogen and phosphorus removal efficiency dropped to $20 \%$ and $62 \%$, respectively, when salt concentration was $5 \% \mathrm{NaCl}$ in the bioreactor (Dinçer and Kargi 2001, Uygur and Kargi 2004). In addition, the salinity stress enhanced the release of both soluble microbial products (SMP) and extracellular polymeric substances (EPS), leading to severe membrane fouling (Park et al., 2015). Furthermore, an increase in the total dissolved solid (TDS) concentration in the bioreactor tank can reduce the osmotic pressure gradient across the FO membrane, causing the declined water flux (Qiu and Ting, 2013).

Among suggested draw solutions (Table1), $\mathrm{NaCl}$ was widely used as an inorganic draw solution in OsMBR systems because it exhibits high water flux at moderate draw solution concentrations, high solubility, and easy storage. For example, Holloway et al.(2015b) used 
$0.5 \mathrm{M} \mathrm{NaCl}$ salt as the draw solution in an OsMBR system with mixed liquor suspended solids (MLSS) of $5 \mathrm{~g} / \mathrm{L}$ and achieved high removal efficiencies for phosphate and chemical oxygen demand $(96 \%)$ for a water flux of $4.3 \mathrm{~L} / \mathrm{m}^{2} \mathrm{~h}$. However, because monovalent ions $\left(\mathrm{Na}^{+}\right.$with a hydrated radius of $0.18 \mathrm{~nm}$ and $\mathrm{Cl}^{-}$with a hydrated radius of $0.19 \mathrm{~nm}$ (Kiriukhin and Collins, 2002)) could easily pass through the FO membrane (membrane pore size: 0.37 $\mathrm{nm}$ ) (Xie et al., 2012), the TDS concentration in the bioreactor increased by approximately 20 g/L after 126 days. To minimize salt leakage, Qiu and Ting (2013) demonstrated that using a divalent salt such as $\mathrm{MgCl}_{2}\left(\mathrm{Mg}^{2+}\right.$ with a hydrated radius of $0.3 \mathrm{~nm}$ (Kiriukhin and Collins, 2002)) in the draw solution in a submerged OsMBR could reach organic matter removal to $98 \%$ and reduce salt leakage compared with an $\mathrm{NaCl}$ draw solution. However, the salt accumulation in the OsMBR system was still high $(>9 \mathrm{~g} / \mathrm{L})$ for an 80 -day operation, because of the reverse transport of $\mathrm{MgCl}_{2}$ from the draw solution and the rejection of dissolved solutes in the feed by the FO membrane. Furthermore, Ansari et al. (2015) used glycine and glucose as the organic draw solutions in OsMBR system to achieve low salt accumulation but the water flux was relatively low (Table 1).

\section{[TABLE 1]}

Up to this date, new OsMBR configurations such as UF-OsMBR, NF-OsMBR, and anaerobic-OsMBR have been studied and obtained the promising results (Holloway et al., 2015b; Yin Tang and Ng, 2014). However, limited nutrient removal in single reactor, reduced salt accumulation, and the membrane fouling in long-term operation is still the major technical challenges to OsMBR application, which motivated the author to carry out this work. To the best knowledge of the authors, this is the first approach to use highly charged organic compound of Ethylenediaminetetraacetic acid disodium (EDTA-2Na) as a draw solution in an attached growth biofilm - OsMBR (AGB-OsMBR) system to simultaneously reduce salt accumulation and membrane fouling. Compared with activated sludge OsMBR, low suspended solids in AGB-OsMBR may cause low viscosity, less cake deposition, and 
less biofouling of the FO membrane. The high charge and large molecular size of EDTA draw solution has high potential to obtain a low reverse salt flux. Moreover, this diluted draw solution was easily recovered using MD membrane since the water flux in MD is not significantly affected by the salt concentration in the solution.

This study aimed to systematically investigate the performance of AGB-OsMBR/MD hybrid system for wastewater treatment using highly charge EDTA as a draw solution. First, the effect of the flow rate on the water flux and reverse salt flux was evaluated using deionized (DI) water as the feed solution. Next, the variation of the water flux and amount of salt accumulation with the operating duration was examined using synthetic wastewater as the feed solution. Then, the nutrient removal efficiency was then determined in the AGB-OsMBR system and the recovery of diluted draw solution was conducted using polytetrafluoroethylene (PTFE, pore size of $0.45 \mu \mathrm{m}$ ) membrane in MD process. Finally, the membrane fouling characteristics were analyzed using scanning electron microscopy and energy dispersive XRay spectroscopy (SEM-EDS), and fourier transform infrared (FTIR) spectroscopy.

\section{Materials and methods}

\subsection{Material and membranes}

EDTA-2Na (purity of $99.0 \%, 25 \mathrm{~kg} / \mathrm{bag}$ ) was purchased from Imperial Chemical Corp, Taiwan. The cellulose triacetate non-woven support (CTA-NW) FO membrane used in this study was supplied by Hydration Technology Innovations (HTIs OsMem ${ }^{\mathrm{TM}}$ CTA Membrane

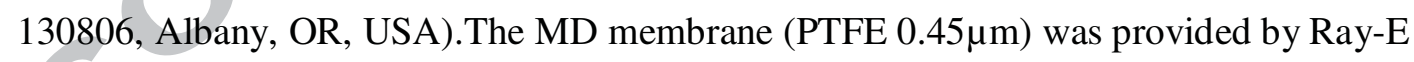
Creative Co., Ltd., Taiwan. Characteristics of the FO and MD membranes were provided in Table 2. The mean pore size, water permeability, the structural parameter of the FO membrane were determined based on reference (Cath et al., 2006; Kong et al., 2014; Xie, 2014), and the mean pore size, porosity of the MD membrane were provided from the manufacturer. The contact angle of FO and MD membranes was measured by using CAM 100 (Opto-Mechatronics P Ltd., India) as shown in Figure S1. 
[TABLE 2]

\subsection{Description of the AGB-OsMBR/MD hybrid system}

A schematic of a laboratory-scale AGB-OsMBR/MD system is shown in Figure 1 with operational conditions listed in Table S1. In this system, an AGB using polyethylene balls ( specific surface area $=12.3 \mathrm{~cm}^{2} / \mathrm{g}$ ) as the biofilm carrier was proposed to replace conventional activated sludge OsMBR. Prior to the AGB-OsMBR operation, activated sludge collected from New Taipei Wastewater Treatment Plant (Taiwan) was seeded to the bioreactor contained polyethylene ball carriers with $60 \%$ filling rate by volume of the bioreactor to acclimatize the biofilm carriers until the removal of total organic carbon (TOC), $\mathrm{NH}_{4}{ }^{+}-\mathrm{N}$, and $\mathrm{PO}_{4}{ }^{3-}-\mathrm{P}$ was stable. As shown in Figure S2, microorganisms fully covered carrier after 60-day acclimatization and the color of biofilm changed from yellow to brown, likely as a result of mature biofilm and good denitrification. An FO module with an effective membrane area of $130 \mathrm{~cm}^{2}$ was fabricated as a tube configuration. Then it was vertically immersed in the bioreactor tank, with the active layer of the membrane facing the feed solution. The bioreactor $(500 \times 125 \times 450 \mathrm{~mm})$ with an effective volume of $8.5 \mathrm{~L}$ was continuously aerated to obtain dissolved oxygen (DO) concentration of $5 \mathrm{mg} / \mathrm{L}$ and to create sufficient hydrodynamic shear force for controlling membrane fouling.

\section{[FIGURE 1]}

The bioreactor was operated using synthetic wastewater delivered from a feed tank placed on a digital scale (BW12KH, Shimadzu, Japan). The level of the liquid in the bioreactor tank was maintained by returning the overflowing liquid to the feed tank. Meanwhile, the draw solution (8L) was pumped into FO membrane tube, whereby water from feed solution will permeate through membrane to dilute draw solution. The water flux was calculated using weight changes of the feed tank, which was then recorded temporally using a digital scale. Salt accumulation in the bioreactor was determined by monitoring the conductivity of the mixed 
liquor by using a conductivity meter (Oakton Instruments, USA). Two peristaltic pumps (Master Flux L/S Drive, Model 7518-00, Taiwan) served to continuously circulate the feed and draw solutions on both sides of the FO membrane. During the entire AGB-OsMBR operation, $200 \mathrm{~mL}$ mixed liquor was withdrawn daily (after $24 \mathrm{~h}$ ) from the bioreactor and settled for $30 \mathrm{~min}$, and the clarified supernatant (old biomass) was then discarded. The water of the mixed liquor was used as the samples to measure dissolved organic carbon (DOC), $\mathrm{NH}_{4}{ }^{+}-\mathrm{N}, \mathrm{NO}_{3}{ }^{-}-\mathrm{N}, \mathrm{NO}_{2}{ }^{-}-\mathrm{N}$, and $\mathrm{PO}_{4}{ }^{3-}-\mathrm{P}$.

The diluted draw solution from AGB-OsMBR system was recovered to its initial concentration through a laboratory-scale cross-flow MD membrane cell (Ray-E Creative Co., Ltd., Taiwan). The membrane cell was made of acrylic and consisted of two semi-cells. Each semi-cell had a flow channel with a depth, width, and length of $0.3,10$, and $10 \mathrm{~cm}$, respectively. A peristaltic pump (Baoding Longer Precision Pump Co., Ltd., Taiwan) with two pump heads was used to circulate the feed and distillate solutions through each semi-cell with a flow rate of $1.5 \mathrm{~L} / \mathrm{min}$. The diluted draw solution controlled temperature of $50 \pm 1{ }^{\circ} \mathrm{C}$ was continuously pumped from a feed reservoir to the membrane cell, and it subsequently returned to the reservoir (Figure S3). DI water was used as the initial distillate stream. The distillate $\left(25 \pm 1^{\circ} \mathrm{C}\right)$ was circulated from a $1.5 \mathrm{~L}$ reservoir through the distillate membrane semi-cell and back to the reservoir. Excess permeating water overflowed into a container, which was continuously weighed on an analytical balance.

\subsection{Feed and draw solutions}

Synthetic wastewater was used as the feed solution to simulate domestic wastewater.

Synthetic wastewater contains glucose, ammonium chloride, potassium dihydrogen orthophosphate, and trace nutrients as described in Table 3. $\mathrm{NaHCO}_{3}$ and $\mathrm{H}_{2} \mathrm{SO}_{4}$ were utilized to adjust the $\mathrm{pH}$ in the AGB-OsMBR reactor to $7 \pm 0.5$. In addition, deionized (DI) water was also used as the feed solution to determine the optimal flow rate and reverse salt flux. The draw solution was prepared by dissolving EDTA-2Na in DI water. Moreover, the formation 
of highly charged EDTA strongly depends on the $\mathrm{pH}$. Therefore, the $\mathrm{pH}$ of the EDTA draw solution was maintained at 8 by using $8 \mathrm{M} \mathrm{NaOH}$, whereby most EDTA were presented as highly charged species $\left(\mathrm{NaEDTA}^{3-}\right.$ and $\left.\mathrm{HEDTA}^{3-}\right)$.

[TABLE 3]

\subsection{Measurement of water flux and reverse salt flux}

The experimental water flux $J_{w}\left(\mathrm{~L} / \mathrm{m}^{2} \mathrm{~h}\right)$ was calculated by measuring the change in the feed container mass with time:

$\mathrm{J}_{\mathrm{w}}=\frac{\Delta V}{A \Delta t}$

where $\Delta V$ is the total increase in the volume of the permeate water (L) collected over a predetermined period, $\Delta t(\mathrm{~h})$, and $A$ is the effective FO and MD membrane area $\left(\mathrm{m}^{2}\right)$. The reverse salt flux $J_{s}\left(\mathrm{~g} / \mathrm{m}^{2} \mathrm{~h}\right)$ of the draw solution was determined on the basis of the amount of salt accumulated in the feed tank:

$\mathrm{J}_{\mathrm{s}}=\frac{V_{t} C_{t}-V_{0} C_{0}}{A t}$

where $C_{t}$ and $V_{t}$ are the concentration and volume of the feed solution measured at time $t$, respectively, and $C_{0}$ and $V_{0}$ are the initial concentration and initial volume of the feed solution, respectively.

Specific reverse salt flux $\left(J_{s} / J_{w}, \mathrm{~g} / \mathrm{L}\right)$, defined as the ratio of salt flux $\left(J_{s}, \mathrm{~g} / \mathrm{m}^{2} \mathrm{~h}\right)$ in the reverse direction and water flux $\left(J_{w}, \mathrm{~L} / \mathrm{m}^{2} \mathrm{~h}\right)$ in the forward direction, was used to estimate the amount of the draw solute lost per liter of water produced during FO.

The salinity and $\mathrm{Na}^{+}$rejection can be obtained from the following equation:

$R=\left(1-\frac{C_{P}}{C_{F i}}\right) 100 \%$

where $R$ is the solute rejection, $C_{\mathrm{P}}$ is the solute concentration in the permeate, and $C_{\mathrm{Fi}}$ is the initial feed concentration 


\subsection{Analytical methods}

The concentrations of $\mathrm{Na}^{+}, \mathrm{PO}_{4}{ }^{3-}-\mathrm{P}, \mathrm{NO}_{3}{ }^{-}-\mathrm{N}, \mathrm{NO}_{2}^{-}-\mathrm{N}$, and $\mathrm{NH}_{4}{ }^{+}-\mathrm{N}$ were analyzed through ion chromatography (Dionex ICS-90) and ultraviolet-visible spectroscopy (Hach DR-4000, Japan). Samples for DOC analysis were first filtered using a $0.45 \mu \mathrm{m}$ filter paper and analyzed using a TOC analyzer (Aurora 1010C, O.I. Analytical Corporation, USA). Mixed liquor suspended solids were analyzed using the 2540 D method described in Standard Methods for the Examination of Water and Wastewater (APHA, 2005). $\mathrm{pH}$ and DO of the bioreactor were measured daily by using a pH meter (Hanna Instruments, HI 9025) and DO meter (Horiba Ltd. Japan, OM-51E), respectively. The fouled membranes were observed and examined using SEM-EDS (JEOL JSM-5600, Tokyo, Japan). The components of the foulants were examined through Fourier transform infrared (FTIR) spectroscopy (BioRad, Philadelphia, PA) with a resolution of $4 \mathrm{~cm}^{-1}$. The viscosity of the solutions was measured with a viscometer (Vibro Viscometer, AD Company, Japan). In addition, the speciation of the complex and charged EDTA in the draw solution at different $\mathrm{pH}$ values were determined using Mineql+ software on the basis of a chemical equilibrium model from the thermodynamic database (Figure S4).

\section{Results and discussions}

\subsection{Effect of operational conditions on water flux and reverse salt transport}

Figure 2 presents a plot of variations in water flux and reverse salt flux versus the flow rate when 1 M EDTA-2Na and DI water were used as the draw and feed solutions, respectively. The water flux gradually rose from 3.01 to $4.35 \mathrm{~L} / \mathrm{m}^{2} \mathrm{~h}$ with an increase in the flow rate from 200 to 2000 $\mathrm{mL} / \mathrm{min}$. An increase in the velocity of the draw solution significantly reduced the internal concentration polarization effect, thus increasing the water flux (Nguyen et al., 2013). In addition, a high flow rate of the draw solution maintained an effective osmotic pressure at the membrane support layer because of the rapid dilution of permeate flow (Abdulwahab et al., 2013). 
Similarly, the reverse salt flux increased from 0.20 to $0.33 \mathrm{~g} / \mathrm{m}^{2} \mathrm{~h}$ with an increase in the flow rate of the draw solution from 200 to $2000 \mathrm{~mL} / \mathrm{min}$. As shown in Figure 2, the change in the water flux between flow rates $1500-2000 \mathrm{~mL} / \mathrm{min}$ was not significant. However, a low reverse salt flux was achieved at $1500 \mathrm{~mL} / \mathrm{min}$. Therefore, the optimal flow rate of $1500 \mathrm{~mL} / \mathrm{min}$ was used in the OsMBR operations to achieve a high water flux $\left(J_{w}=4.34 \mathrm{~L} / \mathrm{m}^{2} \mathrm{~h}\right)$, low reverse salt flux $\left(J_{s}=\right.$ $\left.0.31 \mathrm{~g} / \mathrm{m}^{2} \mathrm{~h}\right)$, and low specific reverse salt flux $\left(J_{s} / J_{w}=0.07 \mathrm{~g} / \mathrm{L}\right)$.

\section{[FIGURE 2]}

\subsection{Various water fluxes and salt accumulations during AGB-OsMBR operation}

Figure $3 \mathrm{a}$ is a plot of water flux and draw solution temperature as a function of time. An average water flux of $3.62 \mathrm{~L} / \mathrm{m}^{2} \mathrm{~h}$ was achieved during a 60 -day operation because most microorganisms were attached to the carrier instead of the membrane, thus avoiding significant membrane fouling. Although the water flux during the AGB-OsMBR operation seemed stable, a few fluctuations in the water flux (from 4.3 to $3.1 \mathrm{~L} / \mathrm{m}^{2} \mathrm{~h}$ ) appeared to be related to changes in the draw and feed solution temperatures. The temperature substantially affected the water flux through semipermeable membranes due to change in water viscosity, which induced a change in the diffusivity of water through the membrane (Cornelissen et al., 2008).

Figure $3 \mathrm{~b}$ depicts that the mixed liquid conductivity in the bioreactor tank increased from 176 to $2018 \mu \mathrm{S} / \mathrm{cm}$ during the 60 -day AGB-OsMBR operation while the conductivity of draw solution was remained in a range of 51.7 to $56.1 \mathrm{mS} / \mathrm{cm}$. This was mainly caused by the transfer of the draw solution (i.e. reverse salt diffusion) into the bioreactor through the FO membrane and the concentration of contaminants in the feed side. However, the salinity concentration in the bioreactor was still low $(<1.5 \mathrm{~g} / \mathrm{L})$ after the 60-day AGB-OsMBR operation and allowed a normal growth of the microbial community to occur. According to (Ye et al., 2009), the maximum salinity concentration in bioreactor tank should not exceed 2 $\mathrm{g} / \mathrm{L}$ to prevent inhibition of the microbial community in OsMBR system. Hence, using highly 
charged EDTA as a draw solution demonstrated to be a promising draw solution for future AGB-OsMBR application to overcome the influence of the build-up of salinity in the bioreactor.

\section{[FIGURE 3]}

\subsection{Characterization of the membrane foulants in AGB-OsMBR operation}

As can be seen in Figures S5a and b, the membrane fouling on used membrane was slight as compared with new membrane. This demonstrated that most microbial community was attached on carrier, which resulted in reduced membrane fouling and maintained water flux (around $3.62 \mathrm{~L} / \mathrm{m}^{2} \mathrm{~h}$ ). Compared with SEM of the original membrane, the fouled membrane indicated the attachment of a thin gel-like fouling layer on the active layer of the used FO membrane (Figures S5c and d). Moreover, the analyzed EDS in Figure S5e showed that the support layer of the used membrane exhibited a new peak of $\mathrm{Na}^{+}$caused by the concentration polarization effect. This explanation is supported by the following reason that the EDTA-2Na solution was in contact with the support layer and could easily attach to the FO membrane surface in the presence of reverse salt diffusion $\left(\mathrm{Na}^{+}\right)$. The components of the biofilm layer on the biocarrier and those of the fouling layer on the FO membrane were analyzed through FTIR at a resolution of $4 \mathrm{~cm}^{-1}$ (Figure S5f). Both samples showed a significant absorbance at 1650 and $1100 \mathrm{~cm}^{-1}$, which is attributable to $\mathrm{C}=\mathrm{O}$ stretching in amides and $\mathrm{C}-\mathrm{O}$ stretching in polysaccharide-like substances, respectively (Ramesh et al., 2006). Because the peaks were derived from polysaccharides and proteins, the results suggested that proteins and polysaccharides appreciably influence membrane fouling. These foulants have been identified as essential agents in MBR and OsMBR systems (Valladares Linares et al., 2012; Wang and $\mathrm{Li}, 2008)$. Compared to fouling layer, the spectra of the biofilm layer on biocarrier was broader than that of the spectra of the fouling layer on FO membrane. This observation showed that using AGB-OsMBR system could reduce membrane fouling significantly. 


\subsection{Nutrient removal during the AGB-OsMBR operation}

The most benefit of AGB-OsMBR hybrid system is that simultaneous nitrification and denitrification process occur in single reactor, which enhanced the nutrient removal appreciably as shown in Figure 4.The results indicated that the average removal efficiency of $\mathrm{NH}_{4}{ }^{+}-\mathrm{N}$ was $99.9 \%$ since most $\mathrm{NH}_{4}{ }^{+}-\mathrm{N}$ was converted into $\mathrm{NO}_{2}{ }^{-}-\mathrm{N}$ and $\mathrm{NO}_{3}{ }^{-}-\mathrm{N}$ under aerobic conditions and the rest of $\mathrm{NH}_{4}{ }^{+}-\mathrm{N}$ was removed by $\mathrm{FO}$ membrane. Therefore the $\mathrm{NH}_{4}{ }^{+}-\mathrm{N}$ concentration in the draw solution was very low $(<0.1 \mathrm{mg} / \mathrm{L})$. Moreover, the concentration of $\mathrm{NO}_{2}{ }^{-}-\mathrm{N}$ and $\mathrm{NO}_{3}{ }^{-}-\mathrm{N}$ in the bioreactor tank was less than $3 \mathrm{mg} / \mathrm{L}$ during the 60 -day operation (Figures $4 \mathrm{~b}$ and $\mathrm{c}$ ), which explained the occurrence of efficient denitrification in the anoxic and anaerobic zones of the attached biofilm in the media. As a result, the average $\mathrm{NO}_{2}{ }^{-} \mathrm{N}$ and $\mathrm{NO}_{3}{ }^{-} \mathrm{N}$ concentrations in the draw solution were very low $\left(0.36\right.$ and $0.56 \mathrm{mg} / \mathrm{L}$ for $\mathrm{NO}_{2}{ }^{-} \mathrm{N}$ and $\mathrm{NO}_{3}{ }^{-}-\mathrm{N}$, respectively).

Figure $4 \mathrm{~d}$ shows that the average removal efficiency of $\mathrm{PO}_{4}{ }^{3-}-\mathrm{P}$ was $99.7 \%$ and this value is higher than those obtained using conventional activated sludge OsMBR (approximately 96\%) (Luo et al., 2015). A possible reason for the high percentage phosphate removal is that because the pore radius of the FO membrane was small $(0.37 \mathrm{~nm})$, all contaminants were rejected because of the steric effect and electrostatic repulsion of the FO membrane. For example, the hydrated radius of $\mathrm{PO}_{4}{ }^{3-}$ was large (0.34 nm) (Kiriukhin and Collins, 2002), and the negatively charged FO membrane repulsed negatively charged phosphate because of the electrostatic force leading to increased $\mathrm{PO}_{4}{ }^{3-}-\mathrm{P}$ removal. Moreover, $\mathrm{PO}_{4}{ }^{3-}-\mathrm{P}$ removal was also enhanced because of biological phosphorus removal for a long sluge retention time (Bao et al., 2007). During the 60 days of the AGB-OsMBR operation, the presence of phosphorusaccumulating organisms in forms of attached growth on biocarriers led to increased removal of phosphorus. This phenomenon was recorded by Guo et al (2011) as the total phosphorus removal in anoxic zone of attached growth on media was kept around 40-50\%. Thus, a very 
low effluent phosphate concentration $\left(0.046 \mathrm{mg} \mathrm{PO}_{4}{ }^{3-}-\mathrm{P} / \mathrm{L}\right)$ was achieved in an AGB-OsMBR hybrid system.

\section{[FIGURE 4]}

\subsection{Recovery of diluted draw solution in MD process}

During AGB-OsMBR operation, the osmotic pressure of draw solution as driving force drawn the clean water from mixed liquid in bioreactor, subsequently the concentration of draw solution was diluted and the MD recovery process was necessary. The MD experiment was repeated three times with three independent PTFE membranes and the high salinity diluted draw solution was kept at $50{ }^{\circ} \mathrm{C}$. Figure 5 illustrated the water flux and re-concentrated feed conductivity in MD process using PTFE membrane $(0.45 \mu \mathrm{m})$ as a function of time. The results shown that the MD water flux slightly decreased from 2.35 to $2.22 \mathrm{~L} / \mathrm{m}^{2} \mathrm{~h}$ during 6 hours due to the decreasing of vapor pressure in salt solution. Meanwhile, the feed conductivity of diluted draw solution was gradually increased versus time and then it was reconcentrated to its initial status $(56.1 \mathrm{mS} / \mathrm{cm})$ after 6-hour MD operation with recovery of 9.8\%. Furthermore, Figure 6 shows that the content of $\mathrm{Na}^{+}$and conductivity increased gradually with the time but the rejection of $\mathrm{Na}^{+}$and conductivity was very high $(>99.7 \%)$. The results revealed that PTFE $0.45 \mu \mathrm{m}$ effectively rejected almost all EDTA ions (indicated by TOC removal of approximately 100\%) in the diluted draw solution during 6-hour MD operation due to large-molecular size of EDTA. The observed overall high rejection can be largely attributed to the MD process where only water vapor is transported through the membrane pores (Duong et al., 2015). The concentration of $\mathrm{Na}^{+}$and conductivity in the final permeate were as low as $25 \pm 0.9 \mathrm{ppm}$ and $110 \pm 2.5 \mu \mathrm{S} / \mathrm{cm}$, respectively, which was suitable for water reuse.

[FIGURE 5]

[FIGURE 6]

\section{Conclusions}


The research demonstrated the feasibility of applying AGB-OsMBR/MD hybrid system for wastewater treatment to simultaneously reduce membrane fouling and enhance nutrient removal. A stable water flux of $3.62 \mathrm{~L} / \mathrm{m}^{2} \mathrm{~h}$ was obtained during a 60-day AGB-OsMBR operation. Moreover, the $\mathrm{NO}_{2}^{-}-\mathrm{N}^{-}$and $\mathrm{NO}_{3}^{-}-\mathrm{N}$ concentrations in the bioreactor were low; this is attributable to good denitrification in the anoxic and anaerobic zones of the biofilm layer during AGB-OsMBR operation. Furthermore, the result of MD recovery showed that PTFE membrane could obtain high salinity rejection (approximately 100\%) and the conductivity of final permeate was as low as $110 \mu \mathrm{S} / \mathrm{cm}$.

\section{Acknowledgements}

This work was supported by the Ministry of Science and Technology of the Republic of

China under the grant number of 101-2221-E-027 -061-MY3. The author are also grateful for the support of Centre for Technology in Water and Wastewater, University of Technology, Sydney, Autralia.

\section{REFERENCES}

1. Abdulwahab, M.I., Majeed, N.S., YousifIssa, S., 2013. Water Recovery from Brine Solution by Forward Osmosis Process. J Eng, 19, 1019-1030.

2. Achilli, A., Cath, T.Y., Marchand, E.A., Childress, A.E., 2009. The forward osmosis membrane bioreactor: A low fouling alternative to MBR processes. Desalination, 239, $10-21$.

3. Alturki, A., McDonald, J., Khan, S.J., Hai, F.I., Price, W.E., Nghiem, L.D., 2012. Performance of a novel osmotic membrane bioreactor (OMBR) system: Flux stability and removal of trace organics. Bioresource Technol, 113, 201-206.

4. Ansari, A.J., Hai, F.I., Guo, W., Ngo, H.H., Price, W.E., Nghiem, L.D., 2015. Selection of forward osmosis draw solutes for subsequent integration with anaerobic treatment to facilitate resource recovery from wastewater. Bioresource Technol, 191, 30-36.

5. APHA, AWWA, WEF, 2005. Standard Methods for the Examination of Waters and 
Wastewaters, 21st ed. American Public Health Association, Washington DC.

6. Bao, L.1., Li, D., Li, X.k., Huang, R.X., Zhang, J., Lv, Y., Xia, G.q., 2007. Phosphorus accumulation by bacteria isolated from a continuous-flow two-sludge system. $\mathrm{J}$ Environ Sci, 19, 391-395.

7. Cath, T.Y., Childress, A.E., Elimelech, M., 2006. Forward osmosis: Principles, applications, and recent developments. J Membrane Sci, 281, 70-87.

8. Cornelissen, E.R., Harmsen, D., de Korte, K.F., Ruiken, C.J., Qin, J.-J., Oo, H., Wessels, L.P., 2008. Membrane fouling and process performance of forward osmosis membranes on activated sludge. J Membrane Sci, 319, 158-168.

9. Duong, H.C., Chivas, A.R., Nelemans, B., Duke, M., Gray, S., Cath, T.Y., Nghiem, L.D., 2015. Treatment of RO brine from CSG produced water by spiral-wound air gap membrane distillation: A pilot study. Desalination, 366, 121-129.

10. Ge, Q., Su, J., Amy, G.L., Chung, T.-S., 2012. Exploration of polyelectrolytes as draw solutes in forward osmosis processes. Water Res, 46, 1318-1326.

11. Guo, W., Ngo, H.-H., Li, J., 2012. A mini-review on membrane fouling. Bioresource Technol, 122, 27-34.

12. Guo, W., Ngo, H.H., Wu, Z., Hu, A.Y.J., Listowski, A., 2011. Application of bioflocculant and nonwoven supporting media for better biological nutrient removal and fouling control in a submerged MBR. Sustain Environ Res, 21, 53-58.

13. Holloway, R.W., Achilli, A., Cath, T.Y., , 2015a. The osmotic membrane bioreactor: a critical review. Environ Sci Water Res Technol, 1, 581-605.

14. Holloway, R.W., Wait, A.S., Fernandes da Silva, A., Herron, J., Schutter, M.D., Lampi, K., Cath, T.Y., 2015b. Long-term pilot scale investigation of novel hybrid ultrafiltration-osmotic membrane bioreactors. Desalination, 363, 64-74.

15. Kiriukhin, M.Y., Collins, K.D., 2002. Dynamic hydration numbers for biologically important ions. Biophys Chem, 99, 155-168.

16. Kong, F.-X., Yang, H.-w., Wu, Y.-q., Wang, X.-m., Xie, Y.F., 2014. Rejection of pharmaceuticals during forward osmosis and prediction by using the solutiondiffusion model. J Membrane Sci, 476, 410-420.

17. Kraume, M., Drews, A., 2010. Membrane Bioreactors in Waste Water Treatment Status and Trends. Chem Eng Technol, 33, 1251-1259.

18. Lay, W.C.L., Zhang, Q., Zhang, J., McDougald, D., Tang, C., Wang, R., Liu, Y., Fane, A.G., 2011. Study of integration of forward osmosis and biological process: Membrane performance under elevated salt environment. Desalination, 283, 123-130. 
19. Le-Clech, P., Chen, V., Fane, T.A.G., 2006. Fouling in membrane bioreactors used in wastewater treatment. J Membrane Sci, 284, 17-53.

20. Luo, W., Hai, F.I., Price, W.E., Nghiem, L.D., 2015. Water extraction from mixed liquor of an aerobic bioreactor by forward osmosis: Membrane fouling and biomass characteristics assessment. Separ Sci Technol, 145, 56-62.

21. Nguyen, N.C., Chen, S.-S., Nguyen, H.T., Ngo, H.H., Guo, W., Hao, C.W., Lin, P.-H., 2015. Applicability of a novel osmotic membrane bioreactor using a specific draw solution in wastewater treatment. Sci Total Environ, 518-519, 586-594.

22. Nguyen, N.C., Chen, S.-S., Nguyen, H.T., Ray, S.S., Ngo, H.H., Guo, W., Lin, P.-H., 2016. Innovative sponge-based moving bed-osmotic membrane bioreactor hybrid system using a new class of draw solution for municipal wastewater treatment. Water Res, 91, 305-313.

23. Nguyen, N.C., Chen, S.-S., Yang, H.-Y., Hau, N.T., 2013. Application of forward osmosis on dewatering of high nutrient sludge. Bioresource Technol, 132, 224-229.

24. Osaka, T., Shirotani, K., Yoshie, S., Tsuneda, S., 2008. Effects of carbon source on denitrification efficiency and microbial community structure in a saline wastewater treatment process. Water Res, 42, 3709-3718.

25. Park, S.H., Park, B., Shon, H.K., Kim, S., 2015. Modeling full-scale osmotic membrane bioreactor systems with high sludge retention and low salt concentration factor for wastewater reclamation. Bioresource Technol, 190, 508-515.

26. Qiu, G., Ting, Y.P., 2013. Osmotic membrane bioreactor for wastewater treatment and the effect of salt accumulation on system performance and microbial community dynamics. Bioresource Technol, 150, 287-297.

27. Ramesh, A., Lee, D.-J., Hong, S.G., 2006. Soluble microbial products (SMP) and soluble extracellular polymeric substances (EPS) from wastewater sludge. Appl Microbiol Biot, 73, 219-225.

28. Valladares Linares, R., Yangali-Quintanilla, V., Li, Z., Amy, G., 2012. NOM and TEP fouling of a forward osmosis (FO) membrane: Foulant identification and cleaning. $\mathrm{J}$ Membrane Sci, 421-422, 217-224.

29. Wang, X., Chang, V.W.C., Tang, C.Y., 2016. Osmotic membrane bioreactor (OMBR) technology for wastewater treatment and reclamation: Advances, challenges, and prospects for the future. J Membrane Sci, 504, 113-132.

30. Wang, X.M., Li, X.Y., 2008. Accumulation of biopolymer clusters in a submerged membrane bioreactor and its effect on membrane fouling. Water Res, 42, 855-862. 
31. Xie, M., Nghiem, L.D., Price, W.E., Elimelech, M., 2012. Comparison of the removal of hydrophobic trace organic contaminants by forward osmosis and reverse osmosis. Water Res, 46, 2683-2692.

32. Xie, M., Nghiem, L. D.,Price, W. E.,Elimelech, M., 2014. Relating rejection of trace organic contaminants to membrane properties in forward osmosis: Measurements, modelling and implications. Water Res, 49, 265-274.

33. Ye, L., Peng, C.-y., Tang, B., Wang, S.-y., Zhao, K.-f., Peng, Y.-z., 2009.

Determination effect of influent salinity and inhibition time on partial nitrification in a sequencing batch reactor treating saline sewage. Desalination, 246, 556-566.

34. Yin Tang, M.K., Ng, H.Y., 2014. Impacts of different draw solutions on a novel anaerobic forward osmosis membrane bioreactor (AnFOMBR). Wa Sci Technol, 69, 2036-2042. 


\section{Figure Captions}

Figure 1. A schematic of the laboratory scale AGB - OsMBR/MD hybrid system.

Figure 2. Water flux and reverse salt flux as a function of draw solution flow rates (Feed solution: DI water; Draw solution: 1 M EDTA-2Na; CTA-NW FO membrane, Membrane orientation: active layer facing the feed solution and $\mathrm{pH}$ : 8). Error bars are based on two replicate experiments.

Figure 3. (a) Various water fluxes during AGB - OsMBR operation, (b) Salt accumulation in bioreactor during AGB - OsMBR operation. (Draw solution: 1 M EDTA-2Na, feed solution: synthetic wastewater, flow rate of $1500 \mathrm{~mL} / \mathrm{min}$, CTA-NW FO membrane, membrane orientation: active layer facing the feed solution).

Figure 4. Nutrient removal efficiency during AGB-OsMBR operation (a) $\mathrm{NH}_{4}{ }^{+}-\mathrm{N}$; (b) $\mathrm{NO}_{2}{ }^{-}-$ $\mathrm{N}$; (c) $\mathrm{NO}_{3}{ }^{-}-\mathrm{N}$; (d) $\mathrm{PO}_{4}{ }^{3-}-\mathrm{P}$. (Draw solution: $1 \mathrm{M}$ EDTA-2Na, feed solution: synthetic wastewater, flow rate of $1500 \mathrm{~mL} / \mathrm{min}, \mathrm{CTA}-\mathrm{NW}$ FO membrane, membrane orientation: active layer facing the feed solution).

Figure 5. Water flux and feed conductivity in MD process as a function of time. (Diluted EDTA-2Na draw solution as feed; Feed temperature $50{ }^{\circ} \mathrm{C}$; Distillate temperature $25^{\circ} \mathrm{C}$; Feed and distillate flow rate $1.5 \mathrm{~L} / \mathrm{min}, \mathrm{MD}$ membrane PTEF with pore size of $0.45 \mu \mathrm{m}$ ).

Figure 6. Conductivity and $\mathrm{Na}^{+}$, TOC removal efficiency in MD recovery process as a function of time. Initial diluted draw solution as feed solution (hot stream):Conductivity of $51700 \pm 103 \mu \mathrm{S} / \mathrm{cm}, \mathrm{Na}^{+}$concentration of $58000 \pm 114 \mathrm{mg} / \mathrm{L}$, and TOC concentration of $120000 \pm 162 \mathrm{mg} / \mathrm{L}$ 


\section{Tables}

Table 1. Comparison of different draw solutions in OsMBR system.

\begin{tabular}{|c|c|c|c|c|c|}
\hline $\begin{array}{l}\text { Draw } \\
\text { solution }\end{array}$ & $\begin{array}{l}\text { Concentration, } \\
\text { M }\end{array}$ & $\begin{array}{l}\text { Increased } \\
\text { bioreactor salt } \\
\text { concentration, } \\
\text { g/L }\end{array}$ & $\begin{array}{l}\text { Declined } \\
\text { water flux, } \\
\mathrm{L} / \mathrm{m}^{2} \mathrm{~h}\end{array}$ & $\begin{array}{l}\text { Operation } \\
\text { time, } \\
\text { day }\end{array}$ & Reference \\
\hline $\begin{array}{l}\text { Sodium } \\
\text { chloride }\end{array}$ & 0.5 & 0.5 to 20 & 4.3 to 1.6 & 126 & $\begin{array}{l}\text { (Holloway } \\
\text { et al., } \\
\text { 2015b) }\end{array}$ \\
\hline $\begin{array}{l}\text { Sodium } \\
\text { chloride }\end{array}$ & 1 & 0.14 to 4.1 & 12 to 3 & 7 & $\begin{array}{l}\text { (Alturki et } \\
\text { al., 2012) }\end{array}$ \\
\hline $\begin{array}{l}\text { Sodium } \\
\text { chloride }\end{array}$ & 1 & 0.4 to 12 & 9 to 5 & 16 & $\begin{array}{l}\text { (Lay et } \\
\text { al., 2011) }\end{array}$ \\
\hline $\begin{array}{l}\text { Magnesium } \\
\text { chloride }\end{array}$ & 0.5 & 3 to 9.7 & 7.50 to 5.62 & 80 & $\begin{array}{l}\text { (Qiu and } \\
\text { Ting, } \\
\text { 2013) }\end{array}$ \\
\hline $\begin{array}{l}\text { Sodium } \\
\text { acetate }\end{array}$ & & 2.41 & 3.5 to $\mathrm{ND}$ & 24 & $\begin{array}{l}\text { (Ansari et } \\
\text { al., 2015) }\end{array}$ \\
\hline Glycine & 1.13 & 3.46 & 3.2 to $\mathrm{ND}$ & 24 & $\begin{array}{l}\text { (Ansari et } \\
\text { al., 2015) }\end{array}$ \\
\hline Glucose & 1.31 & 1.48 & 2.3 to $\mathrm{ND}$ & 24 & $\begin{array}{l}\text { (Ansari et } \\
\text { al., 2015) }\end{array}$ \\
\hline
\end{tabular}


Table 2. The specifications of the FO CTA-NW and MD PTFE membranes

\begin{tabular}{|c|c|c|c|c|c|}
\hline Mean & Thickness & Structural & Water & Contact & Effective area \\
\hline pore & $(\mu \mathrm{m})$ & parameter $S$, & permeability, $A\left(\mathrm{~L} / \mathrm{m}^{2}\right.$ & angle, ${ }^{\circ}$ & per module, \\
\hline size, $\mathrm{nm}$ & & $\mu \mathrm{m}$ & $\mathrm{h} /$ bar) & & $\mathrm{cm}^{2}$ \\
\hline \multicolumn{6}{|c|}{ FO membrane (CTA-ES) } \\
\hline 0.37 & 50 & 700 & 0.51 & 66 & 130 \\
\hline Mean & Thickness & Porosity, \% & - & Contact & Effective area \\
\hline pore & $(\mu \mathrm{m})$ & & & & per module, \\
\hline size, $\mu \mathrm{m}$ & & & & & $\mathrm{cm}^{2}$ \\
\hline \multicolumn{6}{|c|}{ MD membrane (PTFE) } \\
\hline 0.45 & 160 & 82 & - & 118 & 100 \\
\hline
\end{tabular}


Table 3 .Composition of the synthetic wastewater in AGB-OsMBR system.

\begin{tabular}{lll}
\hline Composition & Unit & Concentration \\
\hline Ammonium chloride $\left(\mathrm{NH}_{4} \mathrm{Cl}\right)$ & $(\mathrm{mg} / \mathrm{L})$ & 107 \\
Potassium phosphate $\left(\mathrm{KH}_{2} \mathrm{PO}_{4}\right)$ & $(\mathrm{mg} / \mathrm{L})$ & 18.22 \\
Glucose $\left(\mathrm{C}_{6} \mathrm{H}_{12} \mathrm{O}_{6}\right)$ & $(\mathrm{mg} / \mathrm{L})$ & 450 \\
Cobalt chloride $\left(\mathrm{CoCl}_{2} \cdot 6 \mathrm{H}_{2} \mathrm{O}\right)$ & $(\mathrm{mg} / \mathrm{L})$ & 0.38 \\
Magnesium sulfate $\left(\mathrm{MgSO}_{4} \cdot 7 \mathrm{H}_{2} \mathrm{O}\right)$ & $(\mathrm{mg} / \mathrm{L})$ & 4.82 \\
Ferric chloride $\left(\mathrm{FeCl}_{3}\right)$ & $(\mathrm{mg} / \mathrm{L})$ & 1.52 \\
Calcium chloride $\left(\mathrm{CaCl}_{2} .2 \mathrm{H}_{2} \mathrm{O}\right)$ & $(\mathrm{mg} / \mathrm{L})$ & 0.42 \\
\hline
\end{tabular}




\section{Figures}

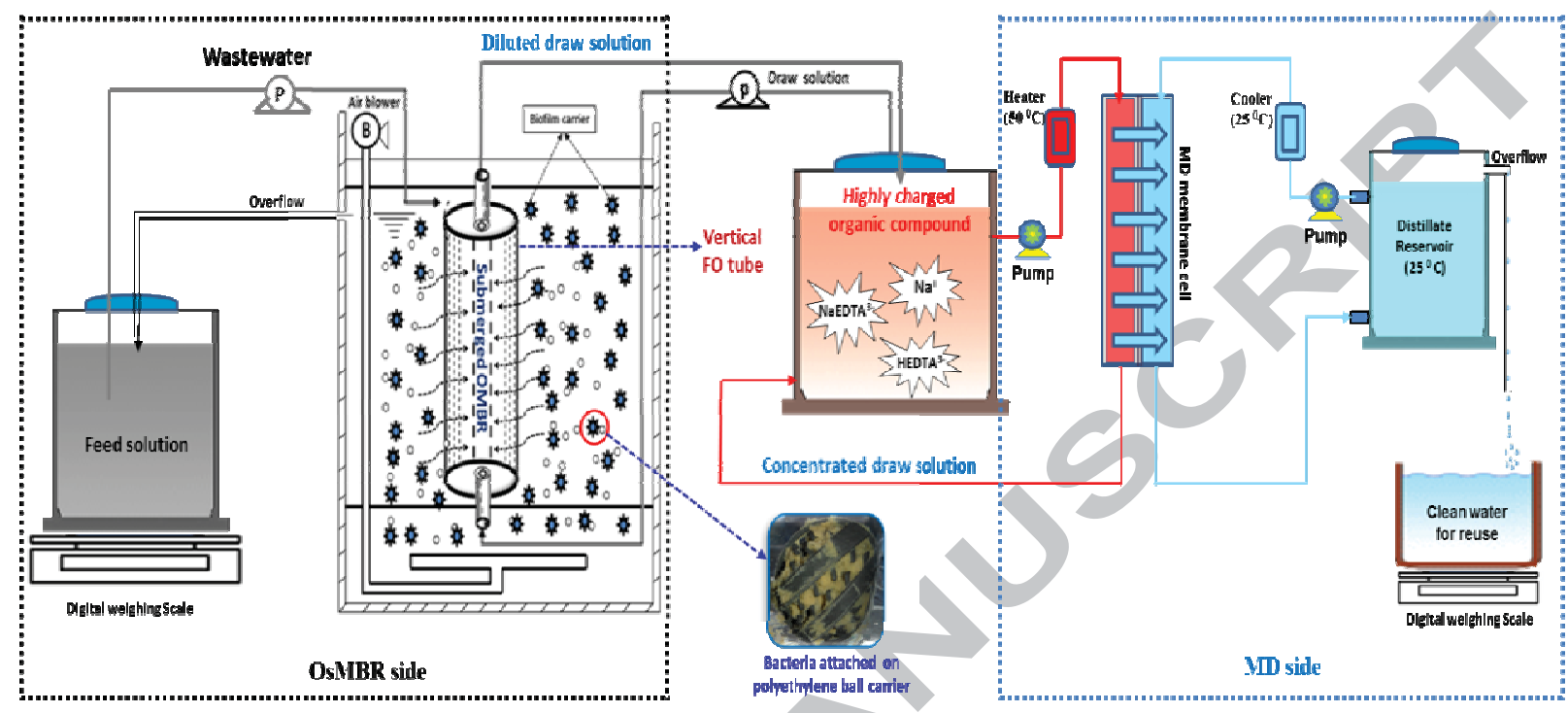

Figure 1. A schematic of the laboratory scale AGB - OsMBR/MD hybrid system. 


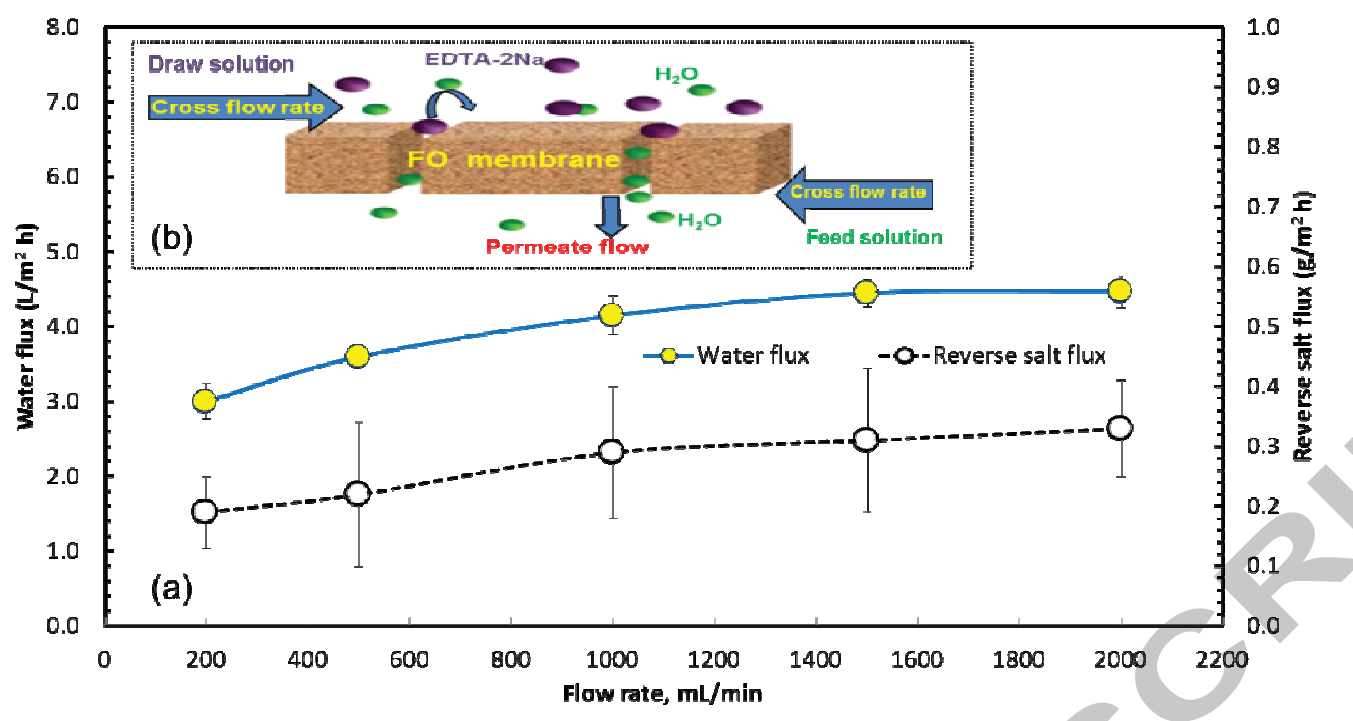

Figure 2. Water flux and reverse salt flux as a function of draw solution flow rates (Feed solution: DI water; Draw solution: 1 M EDTA-2Na; CTA-NW FO membrane, Membrane orientation: active layer 

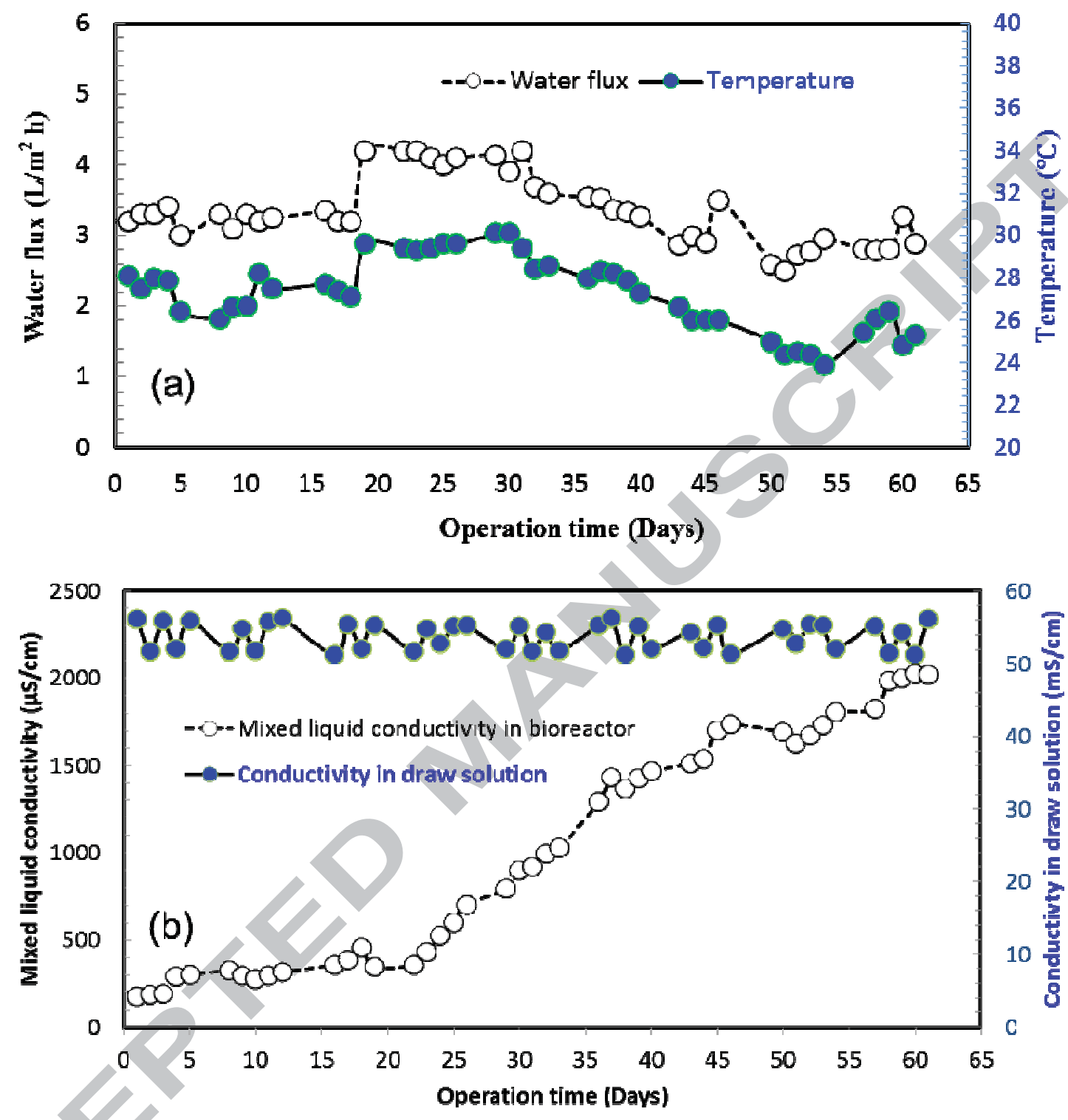

Figure 3. (a) Various water fluxes during AGB - OsMBR operation, (b) Salt accumulation in bioreactor during AGB - OsMBR operation. (Draw solution: $1 \mathrm{M}$ EDTA-2Na, feed solution: synthetic wastewater, flow rate of $1500 \mathrm{~mL} / \mathrm{min}$, CTA-NW FO membrane, membrane orientation: active layer facing the feed solution). 

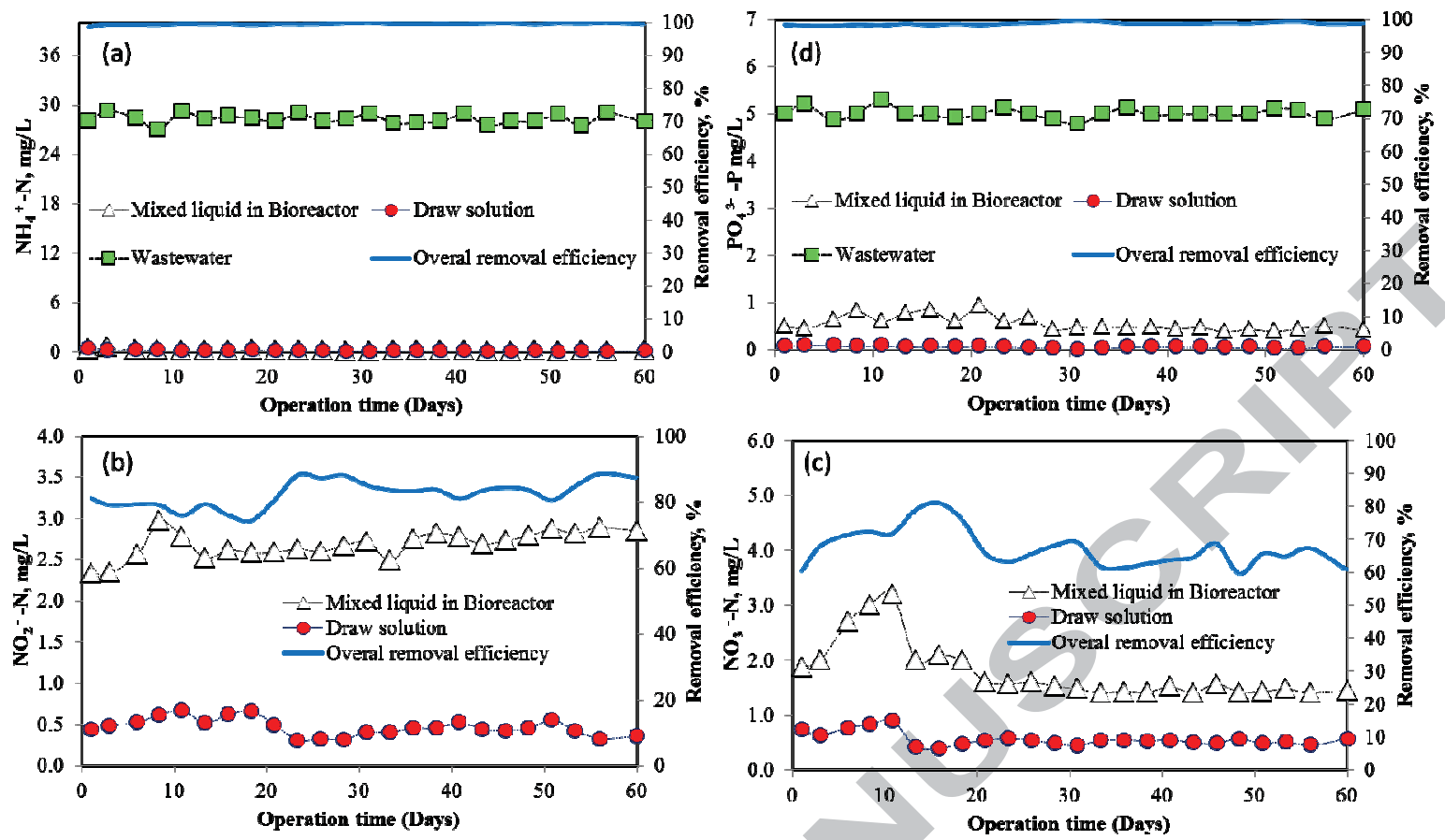

Figure 4. Nutrient removal efficiency during AGB-OsMBR operation (a) $\mathrm{NH}_{4}{ }^{+}-\mathrm{N}$; (b) $\mathrm{NO}_{2}{ }^{-}$

$\mathrm{N}$; (c) $\mathrm{NO}_{3}{ }^{-}-\mathrm{N}$; (d) $\mathrm{PO}_{4}{ }^{3-}-\mathrm{P}$. (Draw solution: 1 M EDTA-2Na, feed solution: synthetic wastewater, flow rate of $1500 \mathrm{~mL} / \mathrm{min}$, CTA-NW FO membrane, membrane orientation: active layer facing the feed solution). 


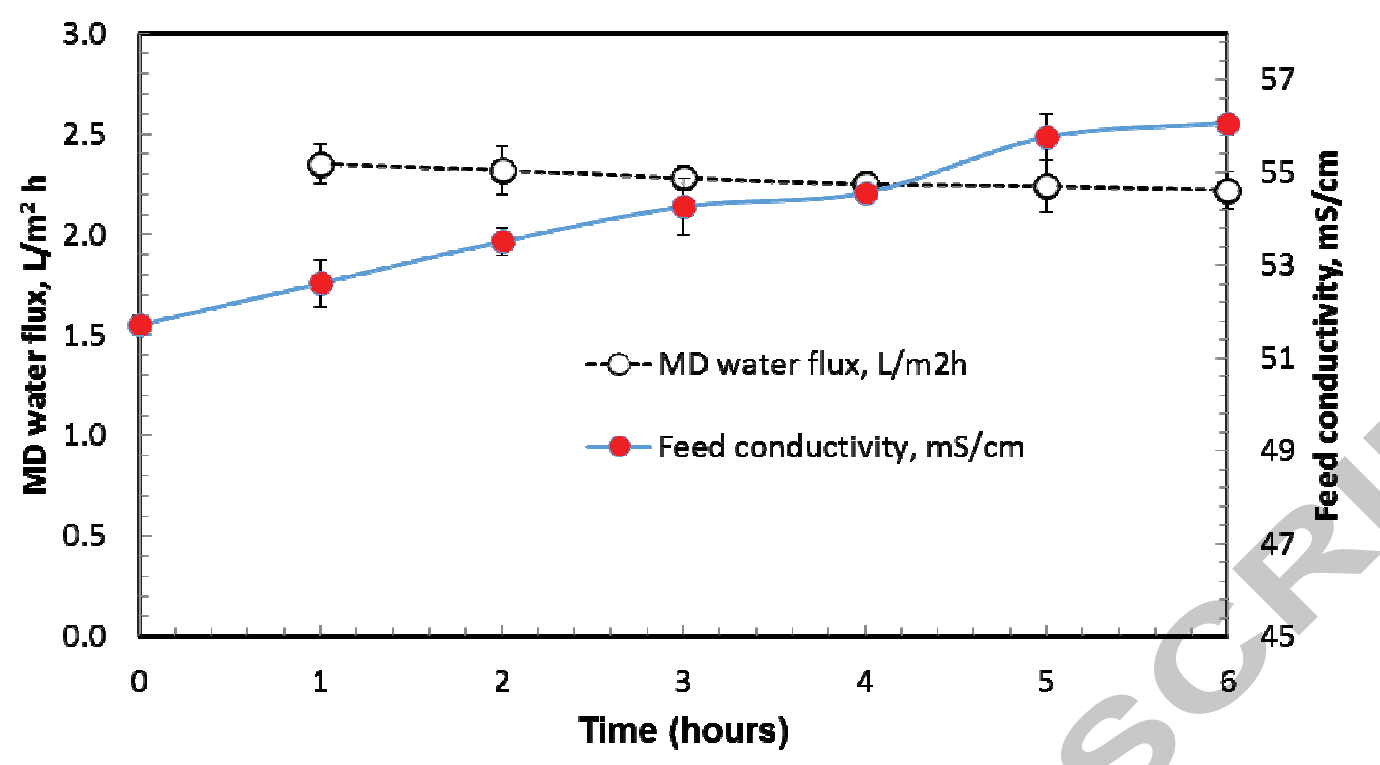

Figure 5. Water flux and feed conductivity in MD process as a function of time. (Diluted EDTA-2Na draw solution as feed; Feed temperature $50{ }^{\circ} \mathrm{C}$; Distillate temperature $25^{\circ} \mathrm{C}$; Feed and distillate flow rate $1.5 \mathrm{~L} / \mathrm{min}, \mathrm{MD}$ membrane PTEF with pore size of $0.45 \mu \mathrm{m}$ ). 


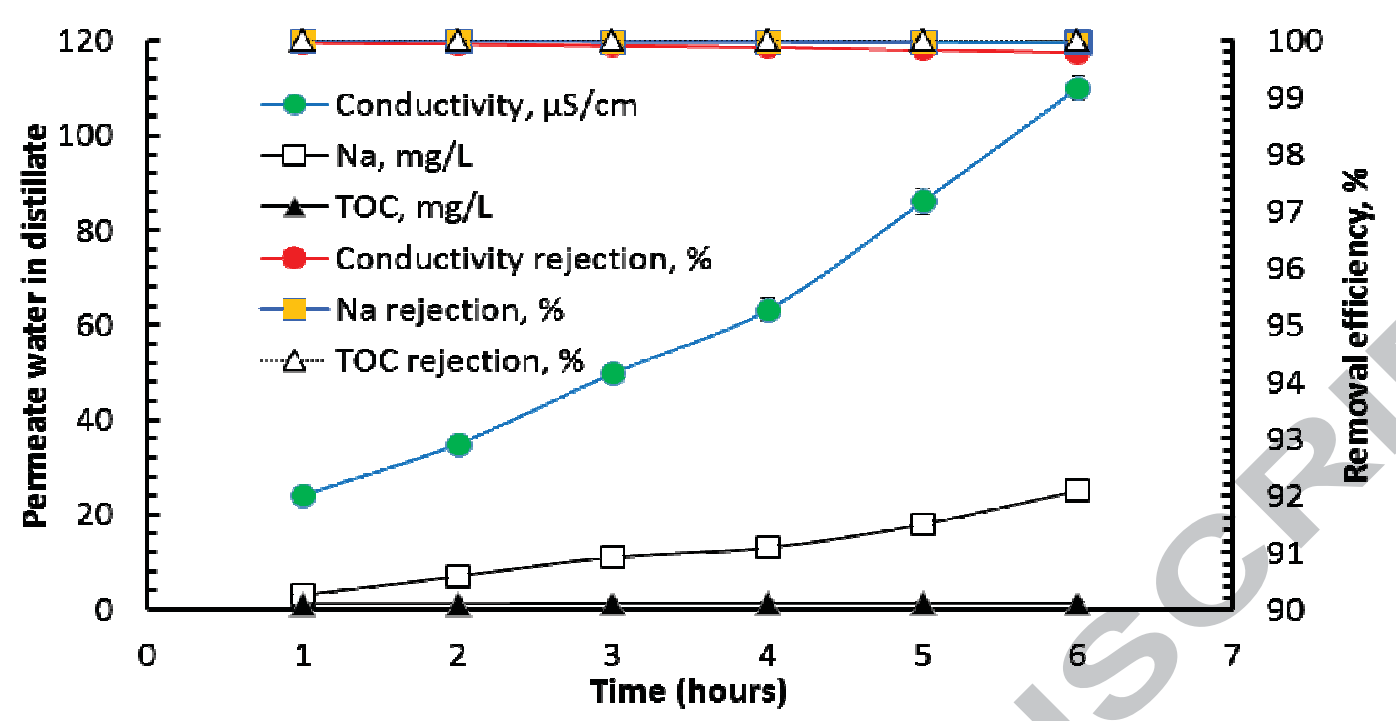

Figure 6. Conductivity and $\mathrm{Na}^{+}$, TOC removal efficiency in MD recovery process as a function of time. Initial diluted draw solution as feed solution (hot stream):Conductivity of $51700 \pm 103 \mu \mathrm{S} / \mathrm{cm}, \mathrm{Na}^{+}$concentration of $58000 \pm 114 \mathrm{mg} / \mathrm{L}$, and TOC concentration of $120000 \pm 162 \mathrm{mg} / \mathrm{L}$ 


\section{ACCEPTED MANUSCRIPT}

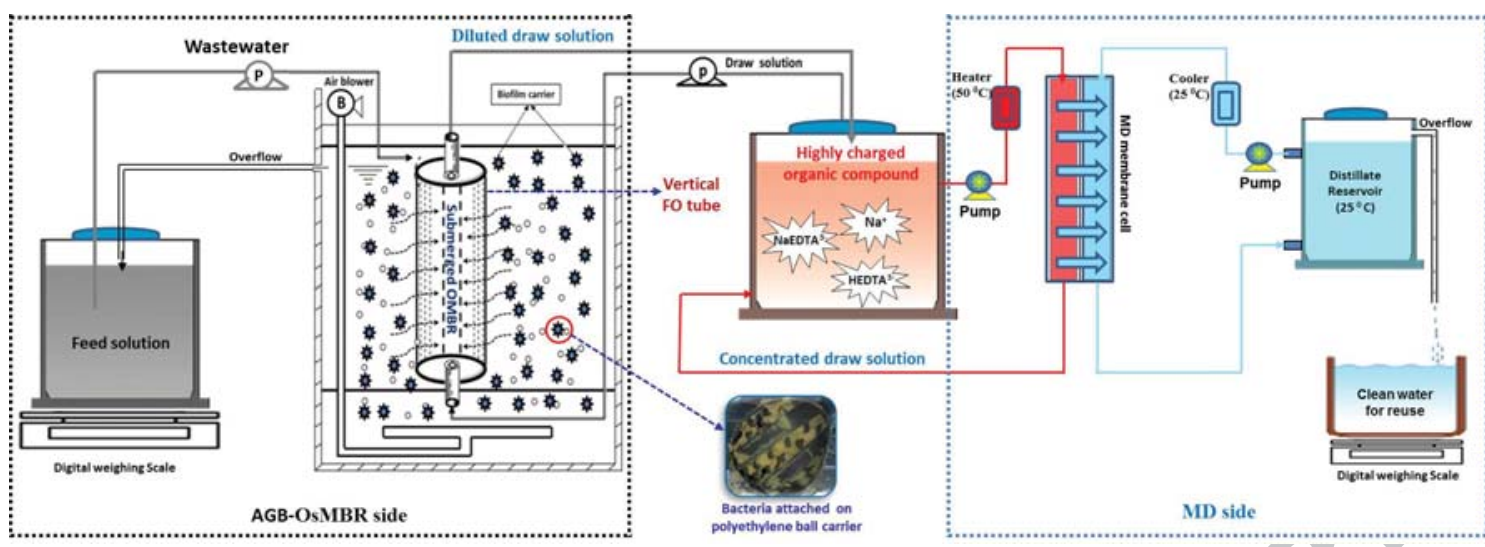




\section{Highlights}

* Highly charged EDTA was investigated as a draw solution in AGB-OsMBR/MD hybrid system

* Low salt accumulation $(<1.5 \mathrm{~g} / \mathrm{L})$ was observed during a 60-day AGB-OsMBR operation

* AGB integrated with an OsMBR system could reduce membrane fouling of FO membrane

* AGB-OsMBR achieved high nutrient removal (99.94\% of $\mathrm{NH}_{4}-\mathrm{N}$ and $99.73 \%$ of $\mathrm{PO}_{4}-\mathrm{P}$ )

* Diluted draw solution could be effectively recovered (100\%) by PTFE MD membrane 